DOI https://doi.org/10.30525/978-9934-588-63-1.21

\title{
MEDICAL REFORM IN CURRENT REALITIES IN UKRAINE
}

\author{
Nadon V. V., Davydov O. O.
}

\section{INTRODUCTION}

The right to life and health care is one of the universally recognized, fundamental, inalienable human rights and freedoms that are subject to state protection. Ukraine is a welfare state whose policy is aimed at creating conditions that ensure the protection of these rights. The Constitution of Ukraine $^{1}$ stipulates that a person, his life and health are recognized in Ukraine as the highest social value (Article 3 ). Life and health are the highest primary social values, on the basis of which all other landmarks and benefits of modern society are formed, determined and evaluated. Health is a component of human anthropic nature, which it is endowed with from birth. On the one hand, the state of health depends on the inherent characteristics of the individual at the time of his birth, and on the other - is determined by the influence of social, hereditary and natural factors and economic and political conditions existing in the state ${ }^{2}$.

Proclaiming the right to health care, medical assistance and the choice of methods of medical intervention in the Constitution of Ukraine (Articles 28, 49), the state undertook to establish social and legal guarantees for the exercise of these rights by every citizen. And today, in Ukrainian law there is a system of private law regulation of human rights as a participant in the relationship of medical care ${ }^{3}$. Constitutional rights, according to O.V. Skrypniuk, "are an important element of the constitutional and legal status of a person, the content of which is determined by the limits of legitimate activity or behavior of a person or persons to satisfy their political, socio-economic, cultural and other social needs" ${ }^{4}$.

O.V. Tikhomirov assesses health as an inalienable and inviolable means of realization of freedoms of external behavior of an individual and access to the use of life's goods. According to the scientist, health is the highest inalienable good of a person, without which many other benefits lose their significance to

\footnotetext{
${ }^{1}$ Конституція України : Закон України від 28.06.1996 p. № 254к/96-BP. URL: https://zakon.rada.gov.ua/ laws/show/254к/96-вр.

2 Загальнообов'язкове державне соціальне медичне страхування в Україні: сучасний стан та стратегія розвитку : монографія. / С.М. Прилипко, О.М. Ярошенко, Т.А. Занфірова, Я.А. Аркатов. Харків : Право, 2017. C. 19.

${ }^{3}$ Миронова Г.А. Приватноправове регулювання особистих немайнових відносин у сфері надання медичної допомоги : монографія. Київ, 2015. С. 24.

${ }_{4}^{4}$ Скрипнюк О.В. Курс сучасного конституційного права України : академічне видання. Харків: Право, 2009. С. 215.
} 
one degree or another. Illness in general changes, reorients the scale of values. Health is a good that allows you to enjoy other benefits that give a person life ${ }^{5}$.

According to Art. 3 Fundamentals of the legislation of Ukraine on health care $^{6}$, health is a state of complete physical, mental and social well-being, and not only the absence of diseases or physical defects. According to A.Ya. Ivanyushkin, the disease does not destroy health, but only restricts the freedom of human life in any particular direction. It is not necessary to equate health with the absence of disease, because then we have to agree with the opinion that there are no healthy people, because there is practically no one who is not a carrier of any disease ${ }^{7}$.

More specific is the interpretation of human health proposed by the World Health Organization in the preamble to its Statute in $1946^{8}:$ a) health is a state of complete physical, mental and social well-being and not merely the absence of disease or infirmity; b) possession of the highest attainable standard of health is one of the fundamental rights of everyone, regardless of race, religion, political opinion, economic or social status; c) the ability to enjoy all the achievements in the field of health care is one of the fundamental rights of everyone; d) States are responsible for the health of their peoples and are obliged to take the necessary social, legal and health measures to protect them.

\section{Regarding the legislative consolidation of the concept of health}

At the present stage of development of the health care system, the quality of medical care is considered to be the main target function and at the same time a criterion of the health care system from its lower link - treatment and prevention facility, to the top - the Ministry of Health of Ukraine. The challenges of managing and evaluating the quality and safety of health care are one of the most important for any health care system. The urgency of quality assurance is especially growing during the period of health care reform ${ }^{9}$, which is being carried out in Ukraine to this day.

Human rights in the field of health care can be divided into two types: 1) general rights in the field of health care, which have all citizens of Ukraine (Article 49 of the Constitution of Ukraine). These rights include the right to: health care, information on factors affecting health, medical care; 2) special

\footnotetext{
${ }^{5}$ Тихомиров А.В. Медицинское право: практическое пособие. Москва : Статут, 1998. С. 10.

${ }^{6}$ Основи законодавства України про охорону здоров’я : Закон України від 19.11.1992 № 2801-XII. URL: https://zakon.rada.gov.ua/laws/show/2801-12 (Last accessed: 09.05.2020).

${ }^{7}$ Иванюшкин А.Я. «Здоровье» и «болезнь» в системе ценностных ориентаций человека. Вестн. Акад. мед. наук СССР. 1982. № 4. С. 32.

8 Статут (Конституція) Всесвітньої організації охорони здоров’я, прийн. 22.07.1946 p. URL: http://zakonl. rada.gov.ua/laws.

${ }_{9}^{9}$ Концепція управління якістю медичної допомоги у галузі охорони здоров’я в Україні на період до 2020 року : Наказ МОЗ України від 01.08.2011 N 454. URL: https://ips.ligazakon.net/document/MOZ13923.
} 
rights that have certain categories of people in the field of health care. This group of rights includes the rights of: family members, pregnant women and mothers, minors, servicemen, the elderly, the disabled, individuals affected by the Chernobyl accident, living in environmentally unfavorable areas, persons serving sentences in places of imprisonment, to receive medical information, etc. ${ }^{10}$.

The right to health care is manifested (actualized) in the ability of a person to apply to medical institutions, preventive institutions for medical, preventive care by concluding appropriate civil law agreements. In exercising the right to health care, a person independently takes measures to protect his or her own health, as well as opportunities to apply to the relevant authorities to protect his or her rights. The person, using the right, can solve questions not only concerning protection of the specified good, but also questions concerning the good - health (to take part in medico-biological experiment, to give consent to any medical intervention, application of methods of diagnostics, prevention or treatment).

The right to health care is a complex right that includes certain independent types of rights: to a safe environment for life and health; for medical care and social services; on safe and healthy working, studying, living and recreation conditions; for qualified medical care; for reliable and timely medical information, etc. ${ }^{11}$.

The proposed medical reform (measures of the Ministry of Health in 2016, 2017 and 2018 under the leadership of Ulyana Suprun to ensure all citizens of Ukraine equal access to quality medical services and restructuring the health care system so that it has a patient at its center), which all citizens of Ukraine are obliged to conclude an agreement on the provision of medical services with the chosen doctor of the relevant state medical institution. It is the duty of citizens to enter into an agreement with a health care institution or a private medical practitioner, the performance of which will make it possible to seek, if necessary, a doctor of a health care institution for primary health care. Medical service activities are related to the right to health, life and personal integrity. That is, health care relations are constitutional, public. In this regard, the legislator puts forward increased requirements for persons engaged in medical activities $^{12}$.

\footnotetext{
${ }^{10}$ Надьон В.В. Правова категорія «конфлікту» як підстава для захисту прав пацієнтів. Забезпечення прав людини четвертого покоління у системі охорони здоров'я : матер. Міжнар. наук.-практ. конф. (12 квіт. 2019 р., м. Ужгород). Ужгород, 2019. С. 90.

${ }^{11}$ Коробцова Н.В. Поняття та зміст права людини на охорону здоров’я. Сучасні проблеми изивілістики: матер. «круглого столу», присвяч. пам'яті проф. Ч.Н. Азімова, (м. Харків, 20 груд. 2013 р.). Харків, 2013. C. 89 (C. 87-90).

12 Коробцова Н.В. Проблемні аспекти реалізації принципу свободи договору в медичних правовідносинах. Проблеми вдосконалення приватноправових механізмів набуття, передачі, здійснення та захисту суб'єктивних ичивільних та сімейних прав : матер. наук.-практ. конф., присвяч. пам'яті
} 
According to paragraph 1.4 of the Procedure for Primary Care (PMD) the main task of the PMD provider is to provide the population with comprehensive and integrated services for comprehensive, continuous and patient-oriented PMD, aimed at meeting the needs of the population in restoring and maintaining health, preventing disease, reducing the need for hospitalization and improving the quality of life ${ }^{13}$.

As a result, those who did not fulfill their obligation to enter into a primary care agreement with a health care facility or physician became restricted in their right to receive primary care. This restriction can be traced precisely when an individual with a disability cannot receive qualified medical care on the grounds that he or she has not entered into a contract with a health care institution or a doctor, and it is not uncommon for a doctor to turn his back on a patient. When the patient needs medical attention. The question arises: is it legal to force people to enter into a contract for the provision of medical services or a contract for the provision of medical care?

According to the provisions of civil law, a contract is an agreement of two or more parties aimed at establishing, changing and terminating civil rights and obligations (Part 1 of Article 626 of the Civil Code of Ukraine). One of the principles of civil law is the freedom of contract (Part 1 of Article 3 of the Civil Code), the parties are free to enter into a contract, choose a contractor and determine the terms of the contract, taking into account the requirements of the Civil Code, other civil law, business practices, reasonableness and fairness (Part 1 of Article 627 of the Civil Code). Thus, one of the principles of civil law is the freedom of contract, which is manifested in the possibility of concluding a contract, the lack of motivation of the parties to enter into contractual relations, the ability to determine the type of future contract and its terms (content).

A contractual obligation of a medical nature is characterized by a dispositive method of legal regulation, as it provides for free self-regulation by the subjects of their behavior on the basis of the principles of law. According to G.A. Mironova, the subjects of legal relations of the medical field (patients, medical organizations and medical workers) enjoy different degrees of freedom of choice of behavior at their discretion, so it is appropriate to talk about the application depending on the type of legal relationship between the subjects of legal relations. In particular, it depends on such special circumstances as the types of medical care, the grounds for its implementation, the subjective composition of legal relations ${ }^{14}$.

\footnotetext{
Ч.Н. Азімова та 20-річчю 3 дня створення каф. цив. права № 2 (Харків, 29 листоп. 2019 р.). Харків : Право, 2019. С. 97. (С. 97-100).

13 Порядок надання первинної медичної допомоги: MO3 України від 19.03.2018 № 504. URL: https://zakon.rada.gov.ua/laws/show/z0348-18.

${ }^{14}$ Миронова Г.А. Приватноправове регулювання особистих немайнових відносин у сфері надання медичної допомоги : монографія. Київ, 2015. С. 47.
} 
On the one hand, life and health are personal intangible human goods, and the use of these goods, in particular, the satisfaction of personal needs related to the maintenance and promotion of health, belongs to the private sphere of man. On the other hand, these benefits are fundamental social values of modern civil society, they are the subject of sharp interest from the community and belong to the sphere of public (state) interest ${ }^{15}$. Thus, with regard to the contractual legal relationship between doctor and patient, they are mainly characterized by a dispositive method of legal regulation. Civil law relations in the field of medical activities arise on the initiative of legally equal and economically independent entities, which voluntarily determine the nature, content and boundaries of their relationship and assume responsibility and risks in connection with the consequences of these legal circumstances. Therefore, the peculiarities of the civil law component are that it is focused on "regulation of relations on the turnover of the product of medical activities between legally and economically independent entities using the inherent forms of civil law forms and methods"

According to the provisions of civil law, no one can force an individual to enter into a contract. However, in practice, although an individual, in the literal sense of the word, is not forced to enter into a contract, but the levers for this have been made (regarding the possibility/impossibility of providing the patient with primary care). According to N.V. Korobtsova, based on the specifics of the actions that make up the concept of "medical care", it can be argued that the person to whom medical care is provided, is usually in a condition that threatens his life, health, and does not have the opportunity or time to freely choose a performer ${ }^{17}$. There is a certain meaning in this thesis, but if a person, according to his physical condition, cannot freely and consciously understand the meaning of his actions, then why oblige him to do so, namely to conclude a civil law contract of a medical nature. It would be more correct, first, to provide a person with professional medical care, and after providing such care, to offer to enter into an appropriate agreement. Then there would be talk of free will of the parties (Part 3 of Article 203 of the Civil Code of Ukraine, the will of the party to the transaction must be free and in accordance with his internal will).

Thus, the contract with the doctor gave the patient the right (opportunity) to primary care (examination, treatment, consultation, etc.). At first glance,

\footnotetext{
15 Миронова Г.А. Приватноправове регулювання особистих немайнових відносин у сфері надання медичної допомоги : монографія. Київ, 2015. С. 48.

${ }^{16}$ Первова Л.Т. Гражданско-правовые проблемы регулирования медицинского обслуживания граждан в РФ : автореф. дис. ... канд. юрид. наук : 12.00.03. Москва, 2006. С. 4.

17 Коробцова Н.В. Проблемні аспекти реалізації принципу свободи договору в медичних правовідносинах. Проблеми вдосконалення приватноправових механізмів набуття, передачі, здійснення та захисту суб'єктивних циивільних та сімейних прав : матер. наук.-практ. конф., присвяч. пам'яті Ч.Н. Азімова та 20-річчю 3 дня створення каф. цив. права № 2 (Харків, 29 листоп. 2019 р.). Харків : Право, 2019. С. 99.
} 
everything is perfect, by choosing a doctor and concluding a contract with him, the patient feels more protected in case of illness, health issues, etc. It should be noted that security (in question) occurs when a patient on his own initiative wishes to enter into a contract with a doctor of his choice, to whom he has entrusted his health, with whom he is willing to communicate, for example, regarding his health. However, in practice there are many cases when a patient is forced to enter into a contract with a doctor ("free doctor" who is less in demand among patients in terms of their professional abilities), on the grounds that he needs to see a doctor, for example, seek professional advice, pass tests, and from March 2020 to get advice on their health (regarding Covid-19) and, if necessary, call an ambulance, etc.

Analyzing the legal relationship that has arisen between the doctor and the patient under the contract, it should be noted that certain medical services by the nature of the provision can be divided into: 1) the provision of medical care by the doctor to the patient; 2) provision of medical services (consultations) to the patient by the doctor.

Thus, medical care is a type of activity that includes a set of measures aimed at rehabilitation and treatment of patients in a condition that at the time of their provision endangers life, health and ability to work and is carried out by professionally trained workers who have the right to do so ${ }^{18}$. Medical care includes medical measures, the failure to provide which can cause significant harm to the health of patients... ${ }^{19}$. Medical service is a set of medical measures without which the patient's health is not endangered ${ }^{20}$. According to Art. 2 of the European Charter of Patients' Rights ${ }^{21}$, everyone has the right to access the medical services he/she needs for health reasons. Medical services must ensure equal access for all without discrimination on the basis of financial resources, place of residence, type of illness or time of treatment.

A separate type of medical service is consultation, which can be provided by a doctor to a patient remotely (for example, telemedicine). It is very popular outside of Ukraine, in Europe and the USA, where consultations in the clinic are

\footnotetext{
18 Рішення Конституційного Суду України у справі за конституційним поданням 66 народних депутатів України щодо відповідності Конституції України (конституційності) Постанови КМУ «Про затвердження платних послуг, які надаються в державних закладах охорони здоров'я та вищих медичних закладах освіти» (справа про платні медичні послуги) від 25.11.1998р., справа № 1-29/98 № 15-рп/98. URL: https://zakon.rada.gov.ua/laws/show/v015p710-98 (Last accessed: 09.05.2020).

19 Про затвердження Програми надання громадянам гарантованої державою безоплатної медичної допомоги : Постанова КМУ від 11.07.2002 р. № 955. URL: https://zakon.rada.gov.ua/laws/show/955-2002-П.

20 Рішення Конституційного Суду України у справі за конституційним поданням 66 народних депутатів України щодо відповідності Конституції України (конституційності) Постанови КМУ «Про затвердження платних послуг, які надаються в державних закладах охорони здоров'я та вищих медичних закладах освіти» (справа про платні медичні послуги) від 25.11.1998 р., справа № 1-29/98 № 15-рп/98. URL: https://zakon.rada.gov.ua/laws/show/v015p710-98 (Last accessed: 09.05.2020).

${ }^{21}$ Свропейська хартія прав пацієнтів. URL: https://phc.org.ua/sites/default/files/uploads/files/hartia.pdf.
} 
very expensive. From 2017, Ukrainian patients began to use telemedicine support. And in conditions of quarantine and forced self-isolation, telemedicine has become very popular. It allows you to consult a specialist and at the same time reduce the risk of catching an infectious disease during a visit to the hospital (clinic). It should be further noted that such a service can be offered (and already practiced) by insurance companies. The telemedicine service is provided by the insurance company by consulting the insured to the medical portal specified in the insurance policy, the assistance connects with the relevant profile doctor and the doctor advises the insured online on the medical issues addressed by the insured. However, such a service will not be available to everyone, if a person does not have computer skills, then accordingly will not be able to use it, so it is necessary to recommend a telephone online consultation for insured persons, so that this service is available to all insured, if to speak about the service provided by the insurance company.

In the aggregate, the categories of medical care and medical services are included in the category of primary medical care.

Primary medical care is medical care that provides counseling, diagnosis and treatment of the most common diseases, injuries, poisonings, pathological, physiological (during pregnancy) conditions, the implementation of preventive measures; referral in accordance with the medical indications of a patient who does not need emergency medical care, to provide him with secondary (specialized) or tertiary (highly specialized) medical care; provision of emergency medical care in case of physical or mental health disorder of a patient who does not need emergency, secondary (specialized) or tertiary (highly specialized) medical care (Article 35-1) ${ }^{22}$.

Thus, entering into a legal relationship with a medical institution, concluding a contract, a person acquires certain subjective rights (to qualified care, choice of doctor, information about their health, medical secrecy), which essentially reveal the content of the right to health care.

It should be noted that the obligation to enter into a contract with a doctor (not taking into account the events of early 2020 with Covid-19), reduced the desire of the population to conclude a health insurance contract, believing that the contract with a doctor will solve all pressing problems with health. This fact is confirmed by the analysis of the statistics of concluded contracts for life and health insurance in 2019, which shows a declining trend in the number of concluded health insurance contracts (compared to 2018), and an increase in the number of life insurance contracts. Thus, the number of concluded health insurance contracts in case of illness decreased by 333.4 thousand units

\footnotetext{
22 Основи законодавства України про охорону здоров’я : Закон України від 19.11.1992 № 2801-XII. URL: https://zakon.rada.gov.ua/laws/show/2801-12 (Last accessed: 09.05.2020).
} 
compared to the corresponding figure as of the end of 2018. In turn, the number of concluded life insurance contracts increased by 163.1 thousand units, compared to the corresponding indicator as of the end of $2018^{23}$.

As a result, individuals with the new health care reform have begun to entrust their health to their contracted physician (and this is ideally a normal situation), and a life insurance contract continues to be an advantage over their lives.

\section{Regarding life and health insurance in Ukraine}

The legal form of insurance relations is an insurance contract. According to Art. 16 of the Law of Ukraine "On Insurance" stipulates that the insurance contract is a written agreement between the insured and the insurer, according to which the insurer undertakes in the event of an insured event to make an insurance payment to the insured or another person specified in the insurance contract in favor of which the contract is concluded (to provide assistance, perform a service, etc.), and the insured undertakes to pay insurance payments within the specified time and fulfill other conditions of the contract.

The Civil Code of Ukraine (hereinafter - the Central Committee of Ukraine) interprets a certain agreement in a slightly different way. Thus, according to Part 1 of Art. 979 of the Civil Code of Ukraine under the insurance contract one party (insurer) undertakes in case of a certain event (insured event) to pay the other party (insured) or another person specified in the contract, a sum of money (insurance payment), and the insured undertakes to pay payments and fulfill other conditions of the contract. An essential condition is the subject. The subject of the insurance contract may be property interests that do not contradict the law and are related to: 1) life, health, ability to work and pension provision (personal insurance); 2) possession, disposal and use of property (property insurance); 3) compensation for damage caused by the insured (liability insurance).

Let's pay attention to personal insurance, namely life and health insurance of an individual under the legislation of Ukraine in a comparative aspect with other countries.

As for health insurance, it should be noted that there is no compulsory health insurance in Ukraine, but anyone can enter into a voluntary health insurance contract. Today there are few such applicants in Ukraine. The explanation for this is the first step of medical reform in Ukraine.

According to V.M. Boretsky, health insurance is a form of social protection of the population in order to provide guarantees to citizens to receive medical care

\footnotetext{
23 Підсумки діяльності страхових компаній за 9 місяців 2019 року. URL: https://www.nfp.gov.ua/files/OgliadRinkiv/SK/sk_9_mis_2019.pdf.
} 
at the expense of the accumulated funds in the event of an insured event ${ }^{24}$. According to V.Yu. Stetsenko, health insurance is a set of legal norms governing public relations regarding the protection of property interests of individuals in receiving medical care in case of insured events specified in the insurance contract or current legislation at the expense of insurance funds, which are formed from insurance premiums ${ }^{25}$.

Today, with the Covid-19 virus, which has covered the whole world, there is a question about the possibility/impossibility of concluding a health insurance contract in Ukraine in case of disability based on the diagnosis of Covid-19 (abbreviated name of the disease caused by coronavirus SARS CoV-2).

It should be noted that voluntary health insurance policies in Ukraine have never covered the treatment of diseases such as HIV/AIDS, hepatitis, tuberculosis, cancer. All of them belong to the group of critical and especially dangerous infectious diseases. This group was replenished at the end of February with a new type of coronavirus. The Ministry of Health has included coronavirus in the list of especially dangerous diseases (Order of the Ministry of Health No. 521 of February 25, 2020). In turn, the World Health Organization on March 11, 2020 gave the outbreak of a new type of coronavirus pandemic status.

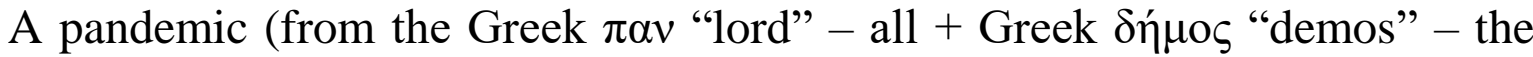
people) - an epidemic characterized by the greatest spread of infectious diseases throughout the country and neighboring countries, many countries, continents ${ }^{26}$. Over the past two millennia, humanity has experienced more than one pandemic. Such pandemics as "Black Death" (plague) in the XIV century, Cholera in the XIX century, and the "Spanish" in 1918-1920 led to great demographic losses and tragedies. Each of them posed a challenge that ultimately stimulated progress through efforts to defeat the invisible enemy ${ }^{27}$.

Returning to today's realities, it should be noted that the pandemic in Ukraine is not covered by an insurance policy. Some insurance companies even state that they do not provide insurance services in case of nationwide force majeure and epidemics.

This issue is being addressed in a completely different way in Europe. According to the Federation of French Insurers, coronavirus disease, in today's reality, has been equated with SARS and is covered by temporary disability

\footnotetext{
${ }^{24}$ Борецкий В.М. Правовые основы медицинского страхования. Проблемы правового регулирования медицинской деятельности : матер. 1-й Всеросс. науч.-практ. конф. (г. Москва, 16 мая 2003 г.). Москва : Издат. группа «Юрист», 2003. С. 318-319.

${ }^{25}$ Стеценко В.Ю. Медичне страхування як складова частина системи страхування (правові аспекти). Форум права. 2009. URL: irbis-nbuv.gov.ua.

${ }^{26}$ Porta Miquel (ed.). Dictionary of Epidemiology. Oxford University Press. 2008. P. 179.

${ }^{27}$ Чума, холера, «іспанка»: як великі пандемії змінювали світ. BBC News Украӥна. URL: https://www.bbc.com/ukrainian/features-52291698.
} 
insurance contracts, i.e. health insurance (protection of the population to provide the necessary counseling and medical care to people in need this assistance in a difficult time of a pandemic).

In addition, Italian insurers have taken a number of measures in the field of health insurance. For example, the largest insurance company in Italy and Europe, Generali, has announced the launch of a program for entrepreneurs to insure employees against coronavirus. The program provides payments of 100 euros to the insured per day for long-term hospitalization and assistance in the amount of 3.000 euros for recovery after resuscitation. The insurance already covers more than 1 million workers across Italy. The company has also set up an International Emergency Fund to combat COVID-19 of up to $€ 100$ million, of which $€ 30$ million will be used to help Italy. Employees of the company are invited to make a contribution by donating 1-2 working hours in favor of the fund.

In Germany, there are two types of health insurance: public and private. It should be noted that the citizens of this country prefer state insurance (87\% of citizens), and only $13 \%$ are insured in private companies. Insurance premiums in Germany are based on the principle of solidarity, i.e. the amount of these premiums does not depend on age or health, but on income. It is through this mechanism of the contribution system that the financing of health insurance is regulated. Citizens with higher incomes indirectly fund lower-income citizens. Paid types of medical services are regulated by German law.

State health insurance covers only the necessary and appropriate types of medical services. In practice, there are special catalogs, if the medical service is not included in the catalog, you will have to pay for it yourself. Thus, during pregnancy there are a number of tests that are not covered by the insurance policy (for example, for antibodies to rubella virus, chlamydia, toxoplasmosis, etc.). They are made at the request and at their own expense by patients ${ }^{28}$.

Students, pensioners, recipients of unemployment benefits, i.e. the least socially protected groups of the population, and workers and employees with a salary of less than 48.600 euros per month are obliged to be included in the state health insurance system.

When receiving private insurance, the funds are paid for each family member separately. Private health insurance is built in Germany on the principle of risk sharing. The younger a person is and the better his health, the lower the monthly payments. Contributions do not depend on income. Relatively young people most often turn to a private insurance company and healthy people, because in the absence of disease, and, consequently, the absence of a large insurance risk,

\footnotetext{
${ }^{28}$ Гюндельма Р. Страховая медицина в Германии. URL: http://www.inostranka-newlife.com.
} 
the sum insured becomes relatively small. Since 2007, Germany has required all citizens to be insured with either a public or a private health insurance company.

The United States is the only developed country in the world where the private insurance model operates, i.e. the state does not guarantee its citizens free access to medical services, and insurance is purchased at its own expense or provided by the employer. The exception is the elderly over the age of 65 and the poor, who can qualify for certain types of medical services under government programs. In other words, access to health services directly depends on the amount of money people have. Because of this, approximately $25 \%$ of Americans do not seek medical attention even in the event of a serious illness.

A completely different approach in Britain, where the health care system is completely nationalized and all people in the country can use the services of the NHS. For citizens, this means that they - with rare exceptions - do not have to pay for medical services out of their own pockets. This is a simple visit to the doctor for the flu, and, for example, a complex procedure, such as in vitro fertilization (IVF). However, in the second case, the woman (not everyone, but only the one who meets certain criteria) receives a limited number of attempts, and in case of failure and if you want to continue the process, you should go to a private clinic.

The Russian system is most similar to the so-called Bismarck model, which was invented and successfully used in Germany, as well as adapted, for example, in the Netherlands and Japan. This is a model of compulsory health insurance.

\section{CONCLUSIONS}

So, today's realities show that the vast majority of the world's leading countries choose insurance medicine or a variant of health care organization in which a significant place is occupied by the insurance component. This necessitates a more thorough study for Ukraine of the possibility of introducing compulsory health insurance. The human right to health care, according to Art. 11 of the European Social Charter, obliges Ukraine, as well as other states, to create appropriate conditions for its implementation.

Regarding the problem of insurance against Covid-19, in Ukraine the solution to this problem should be reflected in insurance cases for life insurance. Coverage of coronavirus treatment and its consequences can be covered by a life insurance policy. There are programs that provide benefits for diagnosing serious and critical illnesses, as well as reimbursement for hospital costs. The essence of such products is as follows. If the insured person has a diagnosis that requires hospitalization, the insurance company covers inpatient treatment. In 
particular, in the intensive care unit. The maximum period of hospitalization, which will be paid by the insurer, can reach 365 days a year.

\section{SUMMARY}

Today, Ukraine is facing one of the first (until the end of unresolved issues) to conduct the second stage of medical reform. This is a very difficult question, especially in today's realities (related to the fight against infectious diseases on COVID-19). The beginning of medical reform in Ukraine began in 2016 (Ulyana Suprun - Acting Minister of Health). Successful or not, time will tell. However, the change of power is a fact of obvious, new achievements, for the better (hopefully), which the Ukrainian people are waiting for. Accordingly, these changes will take place in the second stage of health care reform. One of the main tasks of this stage is to address the issue of compulsory health insurance. Today, the leading insurance companies have many questions. One of the main issues that worries everyone is the question of determining the mandatory insurance cases under the terms of the contract. Also noteworthy is the question of the price of compulsory health insurance, as Ukrainian citizens are accustomed to free medical care. Thus, carrying out the second stage of medical reform for Ukraine is very responsible.

\section{REFERENCES}

1. КонституціяУкраїни : Закон України від 28.06.1996 р. № 254к/96-ВР. URL: https://zakon.rada.gov.ua/laws/show/254к/96-вр.

2. Загальнообов'язкове державне соціальне медичне страхування в Україні: сучасний стан та стратегія розвитку : монографія. / С.М. Прилипко, О.М. Ярошенко, Т.А. Занфірова, Я.А. Аркатов. Харків : Право, 2017. $208 \mathrm{c}$.

3. Миронова Г.А. Приватноправове регулювання особистих немайнових відносин у сфері надання медичної допомоги : монографія. Київ, 2015. 309 c.

4. Скрипнюк О.В. Курс сучасного конституційного права України : академічне видання. Харків : Право, 2009. 466 с.

5. Тихомиров А.В. Медицинское право : практическое пособие. Москва : Статут, 1998. $442 \mathrm{c.}$

6. Основи законодавства України про охорону здоров'я : Закон України від 19.11.1992 № 2801-XII. URL: https://zakon.rada.gov.ua/laws/show/280112 (Last accessed: 09.05.2020).

7. Иванюшкин А.Я. «Здоровье» и «болезнь» в системе ценностных ориентаций человека. Вестн. Акад. мед. наук СССР. 1982. № 4. С. 29-33. 
8. Статут (Конституція) Всесвітньої організації охорони здоров’я, прийн. 22.07.1946 p. URL: http: //zakonl. rada.gov.ua/laws.

9. Концепція управління якістю медичної допомоги у галузі охорони здоров'я в Україні на період до 2020 року : Наказ МО3 України від 01.08.2011 № 454. URL: https://ips.ligazakon.net/document/MOZ13923.

10. Надьон В.В. Правова категорія «конфлікту» як підстава для захисту прав пацієнтів. Забезпечення прав людини четвертого покоління у системі охорони здоров'я : матер. Міжнар. наук.-практ. конф. (12 квіт. 2019 р., м. Ужгород). Ужгород, 2019. 392 с.

11. Коробцова Н.В. Поняття та зміст права людини на охорону здоров'я. Сучасні проблеми цивілістики : матер. «круглого столу», присвяч. пам'яті проф. Ч.Н. Азімова, (м. Харків, 20 груд. 2013 р.). Харків, 2013. C. 87-90.

12. Коробцова Н.В. Проблемні аспекти реалізації принципу свободи договору в медичних правовідносинах. Проблеми вдосконалення приватноправових механізмів набуття, передачі, здійснення та захисту суб'єктивних ичивільних та сімейних прав : матер. наук.-практ. конф., присвяч. пам'яті Ч.Н. Азімова та 20-річчю з дня створення каф. цив. права № 2 (Харків, 29 листоп. 2019 р.). Харків : Право, 2019. С. 97-100.

13. Порядок надання первинної медичної допомоги: МОЗ України від 19.03.2018 № 504. URL: https://zakon.rada.gov.ua/laws/show/z0348-18.

14. Миронова Г.А. Приватноправове регулювання особистих немайнових відносин у сфері надання медичної допомоги : монографія. Київ, 2015. 309 с.

15. Первова Л.Т. Гражданско-правовые проблемы регулирования медицинского обслуживания граждан в РФ : автореф. дис. ... канд. юрид. наук : 12.00.03. Москва, 2006. 24 с.

16. Про затвердження Програми надання громадянам гарантованої державою безоплатної медичної допомоги : Постанова КМУ від 11.07.2002 p. № 955. URL: https://zakon.rada.gov.ua/laws/show/955-2002-п.

17. Рішення Конституційного Суду України у справі за конституційним поданням 66 народних депутатів України щодо відповідності Конституції України (конституційності) Постанови КМУ «Про затвердження платних послуг, які надаються в державних закладах охорони здоров'я та вищих медичних закладах освіти» (справа про платні медичні послуги) від 25.11.1998 р., справа № 1-29/98 № 15-рп/98. URL: https://zakon.rada.gov.ua/ laws/show/v015p710-98 (Last accessed: 09.05.2020).

18. Свропейська хартія прав пацієнтів. URL: https://phc.org.ua/sites/ default/files/uploads/files/hartia.pdf. 
19. Основи законодавства України про охорону здоров'я : Закон України від 19.11.1992 № 2801-XII. URL: https://zakon.rada.gov.ua/laws/ show/2801-12 (Last accessed: 09.05.2020).

20. Підсумки діяльності страхових компаній за 9 місяців 2019 року. URL: https://www.nfp.gov.ua/files/OgliadRinkiv/SK/sk_9_mis_2019.pdf.

21. Борецкий В.М. Правовые основы медицинского страхования. Проблемы правового регулирования медицинской деятельности : матер. 1-й Всеросс. науч.-практ. конф. (г. Москва, 16 мая 2003 г.). Москва : Издат. группа «Юрист», 2003. С. 318-319.

22. Стеценко В.Ю. Медичне страхування як складова частина системи страхування (правові аспекти). Форум права. 2009. URL: irbis-nbuv.gov.ua.

23. Porta Miquel (ed.). Dictionary of Epidemiology. Oxford University Press. 2008. P. 179.

24. Чума, холера, «іспанка»: як великі пандемії змінювали світ. $B B C$ News Україна. URL: https://www.bbc.com/ukrainian/features-52291698.

25. Гюндельман P. Страховая медицина в Германии. URL: http://www.inostranka-newlife.com.

\section{Information about authors:} Nadon V. V.,

Doctor of Legal Sciences, Professor, Professor of the Department of Civil Law № 2 Yaroslav Mudryi National Law University 77, Pushkinska str., Kharkiv, 61024, Ukraine Davydov O. O., Assistent of Oral and Maxillo Facial Surgery Department Kharkov National Medical University 4, Avenue of Science, Kharkiv, 61000, Ukraine 